\title{
Scientific Exegesis in Malay Qur'anic Commentary
}

\author{
Nor Syamimi Mohd ${ }^{1}$, Haziyah Hussin ${ }^{1} \&$ Wan Nasyrudin Wan Abdullah ${ }^{1}$ \\ ${ }^{1}$ Faculty of Islamic Studies, The National University of Malaysia, Malaysia \\ Correspondence: Nor Syamimi Mohd, Department of al-Qur'an and al-Sunnah Studies, Faculty of Islamic \\ Studies, The National University of Malaysia, Malaysia. E-mail: enisya_89@yahoo.com
}

\author{
Received: March 3, 2014 Accepted: March 21, 2014 Online Published: April 29, 2014 \\ doi:10.5539/ass.v10n10p236 \\ URL: http://dx.doi.org/10.5539/ass.v10n10p236
}

\begin{abstract}
Scientific exegesis $\left(\right.$ tafsir $^{c}$ ilmi) is a part of the Qur'anic exegesis which has been around for a long time in the history of Muslim thought. It has grown exponentially in the late nineteenth century and early twentieth century in tandem with the development of knowledge, especially in Western countries as well as the position and attitude of the Muslims in facing current developments. Exegetes and intellectuals in the Middle East, Europe and South Asia are very concerned about scientific exegesis and they apply it in their writing of the interpretation of the Qur'an. Their approach was influenced other scholars indirectly in the Muslim world including Malaysia to apply scientific exegesis in their interpretation scriptures. Therefore, this study aimed to analyze the scientific exegesis in the interpretation of the Qur'an in Malaysia using the method of document analysis of six interpreted scriptures in the Malay language interpretation of Tafsir Nur al-Ihsan, Tafsir al-Qur'an Juz Alif Lam Mim, Tafsir al-Qur'an al-Hakim (Malay version), Tafsir Harian al-Qur'an al-Karim, Tafsir Mubin and Tafsir Pedoman Muttaqin. The results highlighted the interpretation of Malaysian exegete's acceptance of this approach. Muhammad Idris al-Marbawi, Mustafa Abdul Rahman, Salahuddin Abdullah, Omar Khalid and Abdul Hayei Abdul Sukor are exegetes who implement the scientific exegesis in their works. They cite scientific data and current research to explain the verses of the Qur'an to give a better understanding, the meaning of the Qur'anic verses to the reader. In addition, these aspects are described in the definition are intended to prove the oneness and sovereignty of Allah Almighty. The approach in the scientific exegesis of the Qur'an applied by the Malaysian exegetes can be proud of, although it is not as good as other exegetes in particular in the Middle East.
\end{abstract}

Keywords: scientific exegesis, Malay Qur'anic Commentary, Muhammad 'Abduh, Mustafa Abdul Rahman, al-Marbawi

\section{Introduction}

Debate over the relationship between the Qur'an and science among scholars and intellectuals is a sustained polemic since the beginning of Islamic civilization. It is now becoming a hot topic. The rapid development of knowledge and the existence of modern knowledge, especially in science and technology have the findings of the latest science has indirectly mentioned in the Qur'an. These findings are still unknown at the time of revelation. It shows the miracle of the Qur'an as scripture revealed by Allah S.W.T and it is not an invention of the Prophet Muhammad P.B.U.H. This can be seen through the revelations contained in the various chapters of the Qur'an as a manifestation of the wisdom and power of Allah S.W.T as the Creator of the universe. In order to understand these verses, scholars debate over the interpretation of the verses of the Qur'an by looking at the accuracy of the facts of science and modern knowledge to provide readers a deeper understanding of the Qur'an. This interpretation is known as scientific exegesis (tafsir ${ }^{c}$ ilmi). Exegetes and scholars have different opinions about the necessity to interpret based on scientific fact or modern knowledge. There are those who are accepted, reject absolutely and conditionally accepting. Scientific exegesis is in the scope of exegesis based on opinion (tafsir bi al-ra'yi). Most exegetes accepted the exegesis based on opinion with the conditions (rules) and certain guidelines that interpretation is done right and does not conflict with the true meaning of that required by Qur'anic verses. In other words, tafsir bi al-ra'yi can be used as long as is guided by general principles of the Qur'an and Sunnah. Moreover, from the point of writing, the works of the Middle East are very prominent and well-known approach in applying the scientific exegesis of the Qur'an in tafsir commentary at the end of the nineteenth century and early twentieth century. Among the famous works are Tafsir al-Manar, al-Jawahir fi Tafsir al-Qur'an al-Karim and al-Tafsir al-Kawniyyah fi al-Qur'an al-Karim. However, in the context of Malaysia, the development of the exegesis of the writing is a bit late, particularly the scientific exegesis when 
this development is robust and growing in the Middle East. So the question arises, whether the work of exegesis in Malaysia is to apply this approach in the interpretation of the writing? And what are the factors that influence attitudes toward scientific exegesis?

Therefore, this research aims to study the extent to which exegetes in Malaysia concerned with the scientific exegesis of the Qur'an and apply it in their interpretation and factors affecting their scientific exegesis. This paper uses the method of document analysis to study about Tafsir Nur al-Ihsan, Tafsir al-Qur'an Juz Alif Lam Mim, Tafsir al-Qur'an al-Hakim (Malay version), Tafsir Harian al-Qur'an al-Karim, Tafsir Mubin and Tafsir Pedoman Muttaqin. Sample of works selected are only related to analysis exegesis (tafsir tahlili). Analysis of documents in the interpretation of the verses of the Qur'an by the facts of modern science and knowledge that has proven authenticity randomly selected from the interpretation of the scriptures and the data were analyzed descriptively.

\section{The Concept of Tafsir ${ }^{c}$ IImi (Scientific Exegesis)}

\subsection{Definition}

Tafsir ${ }^{c}$ ilmi consists of two words, tafsir and ${ }^{c}$ ilmi. Literally, the word al-tafsir in Arabic comes from the root word al-Fasr which is means clarification, explanation, description and illustration (Ibn Manzur, 1968, p. 55; al-Wasit, 2004, p. 688). Technically, the word tafsir refers to the knowledge and comprehensive understanding of the Book of Allah S.W.T revealed to Prophet Muhammad P.B.U.H and an elucidation of its profound meaning, extraction of its laws, wisdom and maxims (al-Sabuni, 1980, p. 61; al-Zarkashi, 1988, p. 148). It is further called exegesis.

Meanwhile, ${ }^{c}$ ilmi derived from the word ${ }^{c} i l m$ which is means science, knowledge and information. According to Bertrand Russell, science is an attempt to discover, by means of observation and reasoning based on it, first, particular facts about the world, and the laws connecting facts with one another and (in fortune cases) making it possible to predict occurrences (Russell, 1961, p. 8). Besides that, science is the analysis of natural phenomena systematically, logically and objectively with the specific method to accumulate verifiable knowledge that can be trusted (Yusof, 2009, p. 57). This is based on Shaharir's opinion about science.

From the term, there are some definitions given by scholars related to the scientific exegesis (tafsir ${ }^{c}$ ilmi). According to al-Dhahabi, he defines it as a commentary discussing the details of scientific terms in the verses of the Qur'an and trying to produce a variety of knowledge and also some philosophical view (al-Dhahabi, 2005, p. 417). Abu Hajar stated that tafsir $^{c}$ ilmi is the clear interpretation of the verses of the Qur'an based on evidence in terms of science and modern knowledge. This interpretation is emphasized to the public that scientific fact in the Qur'an is one of the miracles of the Qur'an. It is proven that the Qur'an is the revealed word of Allah and it is not said or written by Prophet Muhammad P.B.U.H. The facts are still unknown at the time of revelation (Abu Hajar, 1991, p. 66). Clearly, tafsir ${ }^{c}$ ilmi is an interpretation of the texts of the Qur'an pertaining to the universe, creation, law, health, and others based on theories and finding scientific explanations that have been proven. It is one of the miracles of the Qur'an that serves to give guidance and direction for mankind since it was revealed over 1400 years ago until the Day of Judgment.

\subsection{History of Tafsir ${ }^{c}$ Ilmi and Revolution}

Tafsir ${ }^{c}$ ilmi is one of the trends in the interpretation of the Qur'an, which began in the golden age of the 'Abbasids. It is related to an attempt to align the relationship between the Qur'an and the translation of 'Ulum Ajnabiyyah (external knowledge) as well as modern knowledge that emerged in the Muslim community itself until becoming a strong method in the eleventh century and the next centuries. It then has become a trend becoming apparent and widespread as a stream of commentary in the nineteenth century to the present day (al-Muhtasib, 1973, p. 245).

However, in the twelfth century commentary expansion began through the time of stagnation due to various political and persistent social problems. This condition inhibits the development of thought and Muslim intellectual activity while ijtihad had to be stopped. Thus, the focus of commentary (tafsir) writing is to preserve heritage interpretation works by producing an interpretation of the past in the form of reviews, description or summary of the interpretation of the existing text. This phenomenon led the Muslim world to be weak and fangled in every aspect of life. Muslims encountered the backwardness of thought until the fourteenth century. We can see the glory of the Western countries in terms of knowledge and material in this century. They have the strength that enables them to dominate the Muslim world in every aspect thinking, political, military, economic, and social and at the end scientifically. The clash that occurred between the Muslim and Western Civilization affect the relationship of Muslims with the Qur'an. Qur'an is no longer a guide of their life. Instead, they are 
enchanted by the Western's thought and culture until becoming their way of life in the modern age (al-Syarqawi, 1972, pp. 44-47; al-Muhtasib, 1973, pp. 38 \& 142).

Nevertheless, from the perspective of scientific exegesis showed an excellent trial in the exegesis of the Quran. Al-Ghazali (D. 1111) is the first trigger and calls for scientific exegesis through his work entitled Ihya ${ }^{c}$ Ulum al-Din and Jawahir al-Qur'an (al-Dhahabi, 2005, p. 417; Mazlan, 2002, pp. 32-34). He explained theoretically without applying it. However, subsequent scholars of al-Razi (D. 1209) have been applied this approach widely in his work entitled Tafsir al-Kabir Mafatih wa al-Ghaib. Then continued by later scholars from the Middle East such Muhammad ibn Ahmad al-Iskandari (Kashf al-Asrar'an al-Nuraniyyah al-Qur'aniyyah fi ma yata'allaqu bi al-Ajram al-Samawiyyah wa al-Ardiyyah, Muhammad ${ }^{\mathrm{C}}$ Abduh (D. 1905) (Tafsir al-Manar), Tantawi Jauhari (D. 1940) (al-Jawahir fi Tafsir al-Qur'an al-Karim), Zaghlul El-Najjar (al-Tafsir al-Kawniyyah fi al-Qur'an al-Karim) and others (Ansari, 2001, pp. 91-104; Mazlan, 2002, pp. 34-64; Selamat et al., 2012, pp. 49-67).

At the end of the nineteenth century and early twentieth century, there was a reformation occurred on the exegesis of the Qur'an in Egypt. The reformation was initiated by Muhammad ${ }^{\mathrm{c}}$ Abduh, which aimed to retrieve the Qur'an as a book of guidance to mankind in all aspects of life and demonstrate the relevance of the Qur'an according to the changes in time and the needs of human beings. The idea of thinking of Muhammad ${ }^{\mathrm{c}} \mathrm{Abduh}$ was able to create an innovation in knowledge interpretation contributes in the establishment of madrasah (religion school) which led Muslim scholars and intellectuals such as Muhammad Rashid Rida, Ahmad Mustafa al-Maraghi and Tantawi Jawhari to produce works of contemporary interpretation. Hence, they apply this approach in their work of tafsir indirectly (al-Dhahabi, 1995, p.533; Adnan, 2005, p. 62; Mustaffa, 2006, pp. $1-18)$.

Thus, the reaction of Muslims to the development of science and technology and the influence of the exegesis of the Qur'an are the factors leading the development of the scientific exegesis. This exegesis is considered one of the very prominent modern interpretations nowadays.

\subsection{Scholars' Point of View Regarding Scientific Exegesis}

Exegetes have different opinions about the necessity of interpreting the Qur'an by scientific exegesis (tafsir 'ilmi). There are three groups on commentators' point of view and scholars of tafsir ${ }^{c}$ ilmi (al-Dhahabi, 2005, pp. 417-456; Mazlan, 2002, pp. 34-96). They are:

1) Those who are accepting the tafsir $^{c}$ ilmi. They are Abu Hamid al-Ghazali (D. 1111), Fakhr al-Din al-Razi (D. 1209), Jalal al-Din al-Suyuti (D. 1505) and Sheikh Tantawi Jawhari (D. 1940). They accept this approach because there are general basics of science in the Qur'an.

2) Those who have rejected the tafsir ${ }^{c}$ ilmi. They are Abu Ishaq al-Shatibi (D. 1388) and Sheikh Mahmud al-Shaltut (D. 1963). This group considers the Qur'an which is the book of guidance rather than a book that discusses the problems of science and others.

3) Those who are accepting the tafsir $^{c}$ ilmi with certain conditions. They are Sheikh Muhammad Abu Zahrah (D. 1974), Sheikh 'Abd al-'Azim al-Zarqani and Sheikh Muhammad Tahir ibn 'Ashur (D. 1973).

Most scholars considered tafsir ${ }^{c}$ ilmi with a condition. It is because (Abbas, 1999, p. 20):

1) Tafsir ${ }^{c} i l m i$ is appropriate to the times and current situation.

2) Tafsir ${ }^{c}$ ilmi does not contradict with the words of the Prophet's companions. The opposing opinion about it cannot be accepted.

3) Qur'an is not even a book of poetry and literature. The Qur'an is the guidance book for all the mankind. So, everyone should be diligent to study the Qur'an for preserving the miraculous nature of the Qur'an.

Thus, tafsir ${ }^{c}$ ilmi must comply with the conditions specified by jurists as follows (Abbas, 1999, p. 20):

1) Tafsir ${ }^{c}$ ilmi should not be contrary to the Arabic language and the rules of the science of linguistics ( ${ }^{\circ}$ ilm allughah wa al-nahwu wa al-saraf).

2) Scientific facts cannot be contrary to the relevant Prophet's said (hadith ma 'thur).

3) Do not expand the scope of discussion in interpreting the verses to turn into a science book.

4) Cannot interpret the verses nature of science based on theories alone. Tafsir ${ }^{c} i l m i$ should be based on the relevant fact (thabit) of scientific findings according to the study.

5) Cannot interpret the verses of al-kawniyyat (verses pertaining to the universe) unless they are experts in the field of knowledge and understanding of the interpretation of the Qur'an. 
Obviously, there are opinions about the necessity of scientific exegesis among the scholars. Some of them say that this approach cannot be implemented. However, the majority of them accept scientific exegesis (tafsir ${ }^{c}{ }^{i l m i}$ ) as the scope of the exegesis based on the opinion (tafsir bi al-ra'yi). Therefore, compliance with the requirements outlined by the scholars is very important to make the right interpretation and not contrary to the true meaning of a verse and preserving the nature of the Qur'an as a book of guidance.

\section{Implementing of Tafsir ${ }^{c}$ ilmi in Malaysia}

In the early history of Islam in the Malay Archipelago at the end of the ninth century, most missionaries of Islam were focusing more on spreading the teachings of Islam and attracting the local community to embrace Islam. Teaching and writing interpretations of the Qur'an has not yet specifically done. However, the situation changed after the community received and converted to Islam. Missionaries began to convey the message of the Qur'an and its interpretation (Mazlan et al., 2011, pp. 452-455; Haziyah \& Latifah, 2013, p. 1732). Then, study the interpretation of the Qur'an began in the late seventeenth century and early eighteenth century. However, the activity of writing, translation and study more widely grown in the nineteenth century along with expansion of madrasah (religion school) (Ismail, 1995, pp. 9-10 \& 91; Haziyah \& Latifah, 2013, p. 1736) and continues until now. Based on the Haziyah's study (2012), there are 39 books of Malay Qur'anic Commentary have published starting from the late 1920s to the 1990s. In the twenty-first century, writing the interpretation of the al-Qur'an in Malaysia growing by producing the two other books of tafsir, Tafsir Mubin and Tafsir Pedoman Muttaqin.

\subsection{Application of Scientific Exegesis in Malay Qur'anic Commentary}

The expansion of scientific exegesis of the Qur'an is not only affects the interpretation of the writing on the Middle East, South Asia and Europe (Ansari, 2001, pp. 91-104) but also affected the works of interpretation in Malaysia. The development occurs when there are some local scholars graduated from the Middle East who were influenced by the idea of reformation in the interpretation which initiated by Muhammad ${ }^{\mathrm{c}}$ Abduh. Thus, local scholars of Qur'an such as Syed Sheikh al- Hadi (D. 1934), Sheikh Tahir Jalaluddin (D. 1956) and other scholars in the same thought started to make their step to expand the aspects of interpreting reformation into the local community. They were influenced by reformist of Egypt. In addition, the Malaysian exegetes also considered the works of scientific exegesis and others as the reference and guidance in understanding and interpreting the verses of the Qur'an. Even the existing idea of the interpretation was developed by local scholars especially in the interpretation writing (Mustaffa, 2006, pp. 1-18). Some of the analysis exegesis (tafsir tahlili) can be used to see the implementation of scientific exegesis by scholars in their works of tafsir.

Tafsir Nur al-Ihsan by Muhammad Said Umar (D. 1932) is a Malay exegete of scripture that contains the complete 30 constituents (juzuk) of the Qur'an. He started writing this tafsir in January 1925 and was successfully completed on October 1, 1927. The first Tafsir Nur al-Ihsan was printed in 1934 and is considered the only approach using completed tafsir tahlili (Zulkifli \& Hamza, 2005, pp. 65-82; Mustaffa, 2009, p. 56; Haziyah et al., 2012, pp. 4343-4349). Based on studies conducted by Nurzatil (2009), found that Muhammad Sa'id does not apply the interpretation based on scientific exegesis in his writing of the interpretation. In fact, he tends to follow the rules of textual interpretation (Nurzatil, 2009, p. 136). He was just depended on the understanding of the verses without adding other particular facts related to the science and modern knowledge. This can be seen through his interpretation of Surah al-Hijr verse 22 which says:

"And We have sent the fertilizing winds and sent down water from the sky and given you drink from it. And you are not its retainers (Qur'an, al-Hijr 15: 22)".

When interpreting this verse, Muhammad Sa'id state that Allah asked clouds that containing the rain water down water at the desired place (Sai'd, 1971, p. 290). He is not inclined to adopt the interpretation based on scientific exegesis in the Tafsir Nur al-Ihsan because he used the method applied by the education system of his madrasah (Nurzatil, 2009, p. 141). Via the system, students were asked to read the book (text commentary) by explaining all that in the book without relating to the other comments (Ismail, 1995, p. 107). Moreover, the purpose of interpretation and also be one reason why the matter was not emphasized. The preamble of his commentary book, Tafsir Nur al-Ihsan produced due to requesting of his friends who want to understand the interpretation process. Most of Tafsir books are written in Arabic. Therefore, they require interpretation in Kedah Malay dialect so that the content is easier to be understood (Sa'id, 1971, p. 3-4). Clearly, educational background and the purpose of interpreting the book are the factor that influenced Muhammad Sa'id not to relate the facts of science and the other current study in his work of tafsir. In fact, he was more focused on interpretation in the context of the verse without additional explanations and other information in the interpretation process.

Tafsir al-Qur'an Juz Alif Lam Mim published in 1938 is the second tafsir tahlili after Tafsir Nur al- Ihsan. This work was interpreted by Muhammad Idris al-Marbawi (D.1989) (Nor Azlida, 2010, pp. 36-38; Haziyah, 2012, p. 
4345). He is the first scholar that implemented the scientific exegesis of the Qur'an in his work. This can be seen through the verse 164 of Surah al-Baqarah, which means:

"In the creation of the heavens and the earth and (in) the difference of night and day... (Qur'an, al-Baqarah 2: $164)$ "

He explained that this verse relates to the wisdom of Almighty God who created night and day. There is a place where the night is longer than the day. There is also a place where the day is longer than night and there is a place where the interval between day and night are equal. He explained the pros behind the creation of day and night. People can spend time to relax in the night while they can do their work in the daytime (Nor Azlida, 2010, p. 82).

Al-Marbawi was a special man because he had the opportunity to study at Al-Azhar University. He managed to get a higher degree in Islamic Studies from the university. He also had the opportunity to gain knowledge from the famous scholars in Egypt. They were Sheikh Abu al-A'la al-Falaki (astronomy teacher), Sheikh Mahmud Ghunaym (lecturer at the Faculty of Theology, al-Azhar University), and Sheikh Muhammad Bahith (Scholar of Hanafi stream) (Nor Azlida, 2010, pp. 18-21).

Therefore, his expertise and knowledge is one of the factors al-Marbawi applying knowledge of scientific facts and other modern interpretations of the Qur'an to provide an understanding and knowledge as well as additional information in the book of commentary.

In 1949, book of commentary was using the method of tafsir tahlili entitled Tafsir al-Qur'an al-Hakim (Malay version) by Mustafa Abdul Rahman (D.1968). This book of commentary only contains 27 volumes (penggal) because he died before completing this book. Mustafa Abdul Rahman also linked the verses of the Qur'an with scientific facts and current studies like al-Marbawi. He got many sources of reference consisting of classical masterpieces and contemporary, Islah, science books, history and so on. This book of commentary was a good interpreted book and could be a reference in the interpretation study (Mustaffa, 2009, p. 180; Nurzatil, 2009, p. 53; Haziyah, 2012, p. 4345). In addition, he tried to provide an understanding in any field of knowledge including science, economics, education, psychology, health, and social in the commentary writing as described by him in the preamble to the book of commentary (Mustafa, 1959, pp. 3-4).

In terms of educational background, Mustafa Abdul Rahman was a former student of Maahad II lhya al-Sharif. It is known as an Islah madrasah. He was student of Abu Bakr al-Baqir (D. 1974), the founder of Hizbul Muslimin who was influenced by Eastern thought. This indirectly has given space to the author of Tafsir al-Qur'an al-Hakim to get influenced by the outside particularly Sheikh Muhammad 'Abduh and Rashid Rida Muhammad Sayyid through Tafsir al-Manar and some of the other works that are spread in the Malay region (Mustaffa, 2006, p. 12; Mustaffa, 2009, pp.176-177). We can say that the factors were influencing the way he thought particularly in the scientific exegesis

Some examples of scientific exegesis in Tafsir al-Qur'an al-Hakim is the third verse of Surah al-Ra'd which says:

“.... And from every kind of fruit, it is made in pairs... (Qur'an, al-Ra'd 13: 3)".

$\mathrm{He}$ cites research conducted by botanist that every tree and plant has their pairs. There are pairs in a tree (like a man and woman). Sometimes there is a male on a tree limb and female is on the other tree (Mustafa, 1949, p. 37). It is shown that Mustafa Abdul Rahman was not only relating the interpretation of scientific facts but also supported by a study conducted by scientists to provide a deeper understanding of the meaning of a verse.

Tafsir Harian al-Qur'an al-Karim interpreted by Abdullah Abbas Nasution (D.1987) was written in 1959. It was more focused on the commentary of the Qur'an by interpretation based on opinion (tafsir bi al-ra'yi). However, most interpretations are related to current issues that are happening around his life and the things that happened in Malaya at that time. The interpretation was more focused on economic, political, legal, social justice as well as issues regarding the society (Mazlan, 2008, p. 159). He was not relating the discussion of scientific facts and modern science in his work of interpretation.

The other book of tafsir tahlili is Tafsir Mubin. The author of this book is Salahuddin Abdullah and Omar Khalid. Tafsir Mubin was published in 2009 by Dewan Bahasa dan Pustaka. It is a full version of 30 constituents (juzuk) of the Qur'an. In the interpretation based on scientific exegesis, the author also applied the scientific facts in interpreting the Qur'an. This is reflected in the verse 16 of Surah al-Hijr, which means:

"And indeed We have made the heavens: the stars (the various forms and conditions) and We have beautified the sky for those who see it (Qur'an, al-Hijr 15: 16)". 
He stated that this verse explains that God beautify the sky with al-buruj (constellation), where the stars walked away (Salahuddin \& Omar, 2009, p. 247). It is found that they just explain the verse briefly without citing scientific theories directly.

The latest commentary book is Tafsir Pedoman Muttaqin by Abdul Hayei Abdul Sukor published by the Islamic Development Department (JAKIM). Tafsir will be published by 30 constituents of the two constituents of a year, and the last two constituents are expected to be completed in 2022 (Mustaffa, 2009, pp. 287-292). Abdul Hayei does not interpret the verses of the Qur'an with scientific exegesis based on his statement in the preface of his book. He stated that the field of the miraculous nature of the Qur'an (i'jaz Qur'an) is a difficult field to be explored and requires expertise and understanding enough about the theories and related terminology. Hence, Abdul Hayei does not provide the depth review of scientific information in the Qur'an (Hayei, 2010, p. xli).

However, Abdul Hayei discussed about scientific exegesis indirectly in his interpretation. For example, when interpreting the verse 26 of Surah al-Baqarah, the relevant comparison heathen like mosquitoes. The meaning of the verse is:

"Surely Allah is not ashamed to compare anything, (like) a gnat or more of (because the act is no wiser), so that if those who believe, they know that it is truth from their Lord, and if the who disbelieve will say: "What means Allah by this comparison?" (It): God will make a lot of people cause to err by it, and will make a lot of people are guided by reason, and God will not be lost with comparison reasons, except those who do wrong (Qur'an, al-Baqarah 2: 26)".

He explained that the mosquito has its own magic and privilege. Before becoming a mosquito, it was a larvae living in the water. After becoming a mosquito it flew into the air. In addition, he said despite of the small size of mosquito, but it can bring great disaster. A mosquito can kill a lot of people. It also has an unlimited appetite. Before sucking blood, mosquito will give advance warning to the victim. After that, it began to descend and immediately trunk pierced the skin and transferred the existing viruses to the victims (Hayei, 2010, pp. 113-114). Therefore, Abdul Hayei discussed the scientific facts found in the Qur'an despite it was just a brief discussion.

\section{Conclusion}

Exegetes in Malaysia have different opinion about the necessity of the scientific exegesis of al-Quran. It is noted that Muhammad Sai'd Umar and Abdullah Abbas Nasution did not apply the approach of scientific exegesis. While Muhammad Idris al-Marbawi, Salahuddin Abdullah, Omar Khalid and Abdul Hayei Abdul Sukor just discussed the scientific exegesis briefly. However, Mustafa Abdul Rahman discussed more about it extensively rather than the other exegetes. He discussed the elements of science in the Qur'an in depth by citing specific research scientists to further strengthen the argument given. The difference of the tendency exegete to interpret the Qur'an with the latest knowledge of science in particular happens because every exegete has its own approach and methodology in interpreting the Qur'an. The approach and methodology adopted by them is related to faith, sect, expertise or knowledge, educational background, the purpose of producing the commentary (tafsir), reference sources as well as the current situation. All these aspects affected the exegete in interpreting the verses of the Qur'an. In addition, the interpretation is done by local exegetes are more likely to prove the wisdom, the oneness and sovereignty of Allah Almighty as the Creator of the entire universe. Overall, the majority of the exegetes in Malaysia accepted the scientific exegesis of the Qur'an as one of contemporary commentary in this modern period.

\section{References}

'Abbas, F. H. (1999). I'jaz al-Quran al-Karim. Amman: Dar al-Furqan.

Abdullah, M. (2006). Pengaruh Sayid Rasyid Rida terhadap pengajian tafsir di Malaysia. Al-Bayan Journal of al-Quran \& al-Hadith, 4, 1-18. Retrieved from http://myais.fsktm.um.edu.my/7601/

Abdullah, M. (2009). Khazanah tafsir di Malaysia. Kuala Lumpur: Akademi Pengajian Islam, Universiti Malaya.

Abdullah, S., \& Khalid, O. (2009). Tafsir Mubin. Kuala Lumpur: Dewan Bahasa dan Pustaka.

Abu Hajar, A. 'U. (1991). Al-tafsir al-'ilmi li al-Quran fi mizan. Beirut: Dar al-Qutaibah.

Al- ${ }^{\mathrm{C}}$ Arabiyyah, M. A. (2004). Al-mu'jam al-wasit (4th ed.) al-Qahirah: Maktabat al-Shuruq al-Dawliyah.

Al-Dhahabi, M. H. (2005). Al-tafsir wa al-mufassirun (Vol. 2). al-Qahirah: Dar al-Hadith.

Al-Muhtasib, 'A. M. 'A. S. (1973). Ittijahat al-tafsir fi al-'asr al-hadith (Vol. 1). Beirut : Dar al-Fikr.

Al-Sabuni, M. ‘A. (1980). Al-tibyan fi ' ulum al-Qur'an. Damascus: Maktabah al-Ghazali.

Al-Syarqawi, ‘A. M. (1972). Ittijahat al-tafsir fi Misr fi al-asr al-hadith. Kaherah: Matba’ah al-Khilani. 
Al-Zarkashi, B. A. M. A. (1988). Al-burhan fi al-Quran. Beirut: Dar al-Jil.

Amir, S., Noor, M. M. M., \& Hilmi, A. B. A. (2012). Scientific assimilation in the interpretation of the Qur'an: an approach to Zaghlul El-Najjar's work entitled "Tafsir al-Ayah al-Kawniyyah fi al-Qur'an al-Karim". Al-Bayan Journal of al-Quran \& al-Hadith, 10(2), 49-67. Retrieved from http://www.myjurnal.my/public/issue-view.php?id=3130\&journal_id=165; http://dx.doi.org/10.11136/jqh.1210.02.04

Ansari, Z. I. (2001). Scientific exegesis of the Qur'an. Journal of Qur'anic Studies, 3(1), 91-104. Retrieved from http://www.jstor.org/stable/25728019; http://dx.doi.org/10.3366/jqs.2001.3.1.91

Aziz, N. A. (2010). Metodologi pentafsiran Sheikh Muhammad Idris al-Marbawi dalam kitab Tafsir Quran Marbawi (Unpublished master's dissertation). University of Malaya, Malaysia.

Azizan, N. I. (2009). Tafsir Nur al-Ihsan oleh Muhammad Said bin Umar dan Tafsir al-Qur'an al-Hakim oleh Mustafa Abdul Rahman: Kajian perbandingan metodologi pentafsiran (Unpublished master's dissertation). University of Malaya, Malaysia.

Hussin, H., \& Majid, L. A. (2013). Early development of Quranic exegesis in Malaysia. International Journal of Asian Social Science, $3(8), \quad 1732-1744 . \quad$ Retrieved from http://www.aessweb.com/abstract.php?m=August2013\&id=5007\&aid=2341

Hussin, H., Ibrahim, M., Majid, L. A., Amin, K. M., Mohamad, S., Othman, F. M., ... Shah, F. A. (2012). The trend of Malay Quranic commentary writing in Malaysia in the $20^{\text {th }}$ century. Journal of Applied Sciences Research, 8(8), 4343-4349. Retrieved from http://www.aensiweb.com/jasr/jasr_August_2012.html

Ibn ‘Ashur, S. M. T. (1984). Tafsir al-tahrir wa al-tanwir. Tunis: Dar al-Tunisia li al-Nashr.

Ibn Manzur, A. F. J. A. M. M. (1968). Lisan al- ${ }^{c} A r a b$. Beirut: Dar al-Sadir.

Ibrahim, M. (2002). Sejarah \& pandangan ulama tafsir mengenai tafsir ilmiy. Shah Alam: Karisma Publication Sdn. Bhd.

Ibrahim, M. (2008). Tafsir Harian al-Qur'an al-Karim: Kajian tokoh dan metodologi. Bangi: Fakulti Pengajian Islam, Univerisiti Kebangsaan Malaysia.

Ibrahim, M., Zin, M. Z. M., Sakat, A. A., Nor, M. R. M., Kadir, M. N. A., Awang, J., ... Majid, L. A. (2011). Development of Quranic exegesis in Malay archipelago: A special reference to Malaysia. Advances in Natural and Applied Sciences, 5(5), 452-455. Retrieved from http://www.aensiweb.com/anas_Dec_special_2011.html

Othman, M. Y. (2009). Sains, masyarakat dan agama. Kuala Lumpur: Utusan Publications \& Distributors Sdn. Bhd.

Rahman, M. A. (1959a). Tafsir al-Quran al-Hakim Bahasa Melayu (Vol. 1). Pulau Pinang: Persama Press.

Rahman, M. A. (1959b). Tafsir al-Quran al-Hakim Bahasa Melayu (Vol. 13). Pulau Pinang: Persama Press.

Russell, B. (1961). Religion and Science. London: Oxford University Press.

Sukor, A. H. A. (2010). Tafsir Pedoman Muttaqin (Vol. 1). Putrajaya: Jabatan Kemajuan Islam Malaysia.

Umar, M. S. B. (1971a). Tafsir Nur al-Ihsan (Vol. 1). Pulau Pinang: Percetakan al-Muarif Sdn.Bhd.

Umar, M. S. B. (1971b). Tafsir Nur al-Ihsan (Vol. 2). Pulau Pinang: Percetakan al-Muarif Sdn.Bhd.

Yusof, A. M. (2005). Al-Imam Muhammad 'Abduh: tokoh pembaharuan ilmu tafsir. (Unpublished doctoral thesis). The National University of Malaysia, Malaysia.

Yusoff, I. (1995). Perkembangan pengajian dan penulisan tafsir di Malaysia. (Unpublished doctoral thesis). University of Malaya, Malaysia.

Yusoff, Z. M., \& Muhammad, H. (2005). Biografi Haji Muhammad Said dan sejarah penulisan Tafsir Nur al-Ehsan. Al-Bayan Journal of al-Quran and al-Hadith, 3, 65-82. Retrieved from http://myais.fsktm.um.edu.my/7092/

\section{Copyrights}

Copyright for this article is retained by the author(s), with first publication rights granted to the journal.

This is an open-access article distributed under the terms and conditions of the Creative Commons Attribution license (http://creativecommons.org/licenses/by/3.0/). 